\title{
TELECOMMUNICATION DIRECTIVES AND ITS RELATION TO TURKISH REGULATIONS
}

\author{
Telekomünikasyon Direktifleri ve Türk Mevzuatıyla Bağlantısı
}

Doç. Dr. Hüseyin ALTAŞ*

I. Introduction, II. Authorization Directive, III. Access Directive, V. The Developments That Are Brought Forward By The European Union Reform Package Dated November 13, 2007, VI. Conclusion

\section{ÖZET}

Avrupa Birliği, 1980'li yılların başlarından bu zamana kadar, pazarın liberalleştirilmesi, telekomünikasyon sektörünün ilgili sektörlerle birleştirilerek tek bir sektör oluşturulması ve üye ülkelerin yasalarının uyumlu hale getirilmesi için telekomünikasyon sektöründe birçok reform yapmıştır. Avrupa Birliği'ne tam üye adayı olan Türkiye de Birliğin üyelik gerekliliklerini yerine getirebilmek için Ulusal Programında Avrupa Birliği üye ülkelerin yasalarına uyumluluk, pazarın tam liberalleşmeye hazırlanması, Avrupa Birliği yasalarına tam uygunluk için gereken çalışmaların yapılması ve bilişim teknolojisi altyapısının kurulması olmak üzere başlıca dört alanda yükümlülük üstlenmiştir. Buna karşın ulusal otorite belirtilen amaçlara ulaşmak için birçok düzenleme yapar ve iç pazarı belirli oranda liberalleştirirken, Avrupa Birliği'nin parçası olan ulusal organlar için temel bir soru ortada durmaktadır, verimliliği arttırmak ve iç pazarlardan uyumlu bir tek pazar yaratmak sistematik olarak yeni kural setleri üretmekle mümkün müdür? Görülmektedir ki, bu zamana kadar bu neviden üst yapı kurallarının kabulünde ve uygulanmasında ulusal otoritelerin yarattığı çeşitlilik ve farklılık ulusal operatörlerin hizmetlerini Avrupa'nın başka devletlerinde de sunması noktasında dezavantaj yaratmaktadır. Açıktır ki, bu tipte ortaya çıkan

\footnotetext{
* Associate Professor of Law, Ankara University Faculty of Law.
} 
sorunlar yeni kurallar kabul edilerek çözülemez ve yeni bir yaklaşım tarzı gerekmektedir. Avrupa Birliği çapındaki bütün ulusal düzenleyici otoritelerin aynı çatı altında birleştirilmesi bu tipte sorunlar için etkin bir çözüm olacağı gibi topluluğun amaçlarına ulaşmasına da yardımcı olabilir.

Anahtar Kelimeler: Avrupa Birliği telekomünikasyon mevzuatı, Türk telekomünikasyon mevzuat1, Avrupa'da telekomünikasyon sektörünün düzenlenişi, telekomünikasyon sektörünün liberalleştirilmesi, ulusal düzenleyici otoriteler

\section{ABSTRACT}

Many reforms took place in the European Union regarding the telecommunication sector, beginning from early 80 's to date, at the purposes of liberalization of the market, consolidating telecommunication sector and other related sectors as a single market and harmonizing the legislation of the member countries. As a candidate of the European Union membership, Turkey assumed four types of obligations within the framework of the national program about telecommunication sector in order to full fill membership requirements of the Union. The first of the mentioned obligations is to ensure compliance with the legislation of the European Union, others are to prepare the markets for full liberalization, to commence studies to ensure compliance with the legislation of the European Union and to establish information technologies infrastructure. But while the national legislator accepted series of regulations and liberalized the internal market in some degree to achieve the mentioned goals, there is still a fundamental question for the national bodies of the European Union about the European Union's main policy, namely whether if it is possible to raise efficiency and harmonize the internal market in a single market just by systematically organizing the rules. So far the diversified procedures that encountered in adopting such rules according to national legislation appear to be a handicap for the national operators to extend their services into other states of Europe. It's clear that these kinds of problems can not be solved by forming new directives nor new rules but another approach should be accepted. Collecting all the National Regulating Authorities under the same roof could be the solution for these kinds of problems and also it can help the Union to achieve the goals that has been accepted.

Keywords: Telecommunication regulations in European Union, telecommunication regulations in Turkey, harmonizing telecommunication sector in Europe, liberalization of the telecommunication sector, national regulating authorities 


\section{Introduction}

During the early 80 's, many reforms took place in the European Union regarding the telecommunication sector. It is possible to divide this time period into three phases. The first phase, initiated the liberalization of some services; followed by a second phase, which implemented full liberalization of the market; and a third phase, which consolidated telecommunication, radio-television broadcasting and information technologies markets as a single sector with the aim of providing effective competition to enable consumers to obtain better services ${ }^{1}$.

The reasons triggering the European Union to regulate and liberalize this sector may be due to several factors that include the relatively small scale and superficiality of national markets (due to state monopolies), the disparity between member states, the fragmented structure of the sector, distortions in commerce, and the concerns to define a common attitude on behalf of the European Union during the negotiations held with the World Trade Organization.

Studies relating to potential telecommunication reforms began in 1985 , with continual advancements in the Telecommunication Green Paper $^{2}$ of 1987, the Review presenting the results of full liberalization in $1992^{3}$, the telecommunication reform package prepared in 1998 regarding the integration of full liberalization with the Union's legislation, the Communication Communiqué published in 1999, and the 2000 telecommunication reform package $^{4}$.

\footnotetext{
${ }^{1}$ Zerey G.: Avrupa Birliği Elektronik Haberleşme Müktesebatına Göre Telekomünikasyon Sektörünün Düzenlenmesi (Sunum Metni), (Regulation of Telecommunication Sector according to European Union's Electronic Communication Acquis CommunautairePresentation Text) İstanbul2006, http://www.tgm.gov.tr/EtkinlikIer/UIusal_Etkinlikler/ sunumlar/ gzerey_sunum_3.pps\#256,1,AVRUPA BİRLİĞİ ELEKTRONIK HABERLEŞME MÜKTESEBATINA GÖRE TELEKOMÜNIKASYON SEKTÖRÜNÜN DÜZENLENMESİ (13.12.2007).

${ }^{2}$ Green Paper on the Development of a Common Market for Telecommunications Services and Eguipment, (June 1987).

3 Communication on the Consultation on the Review of the Situation in the Telecommunications Services Sector, (April 1993).

4 Kuzey P.: Avrupa Birliği'ne Üyelik Perspektifinde Türkiye'de Telekomünikasyon Sektörüne Bir Bakış (Approach to Telecommunication Sector in Turkey in the Perspective of Membership to European Union), Bütçe Dünyası, C.2, S.25, Bahar 2007, p.30; Dokuzuncu Kalkınma Plan1-Ninth Development Plan (2007-2013), Bilgi ve İletişim Teknolojileri Özel İhtisas Komisyonu, Telekomünikasyon Alt Komisyonu Raporu (Information and Communication Technologies Specialized Commission, Telecommunication Sub-commission), June 2006, p.33-34 (Sub-commission Report) www.bilgitoplumu.gov.tr/yayin/Telekomünikasyon_OIK_Raporu.pdf (08.12.2007).
} 
In 1998, once the goal of full telecommunications liberalization was realized in all the member states, new regulations were needed, and a regulatory framework was prepared to this end. The meeting held in Lisbon on 23-24 March 2000 provided the basis for the New Regulatory Framework in the telecommunication sector. The New Regulatory Framework was organized to encourage new entries to the market, provide political stability, protect new entrants from the negative attitudes of the operators having Significant Market Power (hereinafter "SMP"), minimize intervention to the market, provide competition and opportunity to choose, and ensure protection of users' interests. In the light of these reforms, the member states were obliged to harmonize their legislation in line with these aims.

In order to fullfill requirements for membership candidacy of the European Union, Turkey assumed four types of obligations in the telecommunication sector within the framework of the national program that Turkey prepared in 2003 and reviewed in 2005. The first of these obligations is to ensure compliance with the legislation of the European Union in the telecommunication sector. Other obligations are to prepare the markets for full liberalization, to commence studies to ensure compliance with the legislation of the European Union, and to establish information technologies infrastructure ${ }^{6}$.

The priorities within the framework of the European Union's legislation were to effectively implement the rules defined in the Accession Partnership Paper prepared by the European Union in 2003, in relation to leased lines, protection of data, interconnection and universal service, carrier selection, number portability, tariffs and license; and to prepare a timetable related to the New Regulatory Framework accepted in 2002, and to reinforce the power of the independent authority ${ }^{7}$.

\section{Authorizatien Directive}

Authorization means granting of authority to companies for provision of telecommunication services and/or establishment and operations of telecommunication infrastructures within the framework of certain conditions.

The aim of the Authorization Directive 2002/20/EC of 7 March 2002 is defined in Article 1 of the Directive as: "the aim of this Directive is to implement an internal market in electronic communication networks and services through the harmonization and simplification of authorization rules and conditions in order to facilitate their provision throughout the Community". As noted from this definition, the aim of the Directive is to

\footnotetext{
${ }^{5}$ Kuzey, p.31; Sub-commission Report, p.45.

${ }^{6}$ Report of Sub-commission, p.33-34.

${ }^{7}$ Report of Sub-commission, p.33-34.
} 
simplify the terms and conditions of authorization, and besides, to ensure that all member states are subject to the same rules. In addition, the Directive restricts the conditions to be set by the member states for entry into the market and determines the rights of using radio frequencies and numbers, the conditions for implementing new authorization system and the fees ${ }^{8}$.

The most important innovation introduced by this directive that regulates the entry into the market is that it does not anticipate individual licensing of electronic communications networks and services, and it deems only general authorization sufficient unless scarce resources are allocated. Likewise, it is set forth in subsection 2 of Article 3 of the directive that the provision of electronic communications networks or electronic communications services may only be subject to a general authorization and the undertaking concerned may be required to submit a notification, and after this notification, an administrative act or an explicit decision may be obtained from the National Regulatory Authority (hereinafter "NRA"). It is considered sufficient that the notification mentioned in this article should have the content that allows the NRA to keep a register or list of providers of electronic communications networks and services. This system is evaluated to be a simpler and easier method in comparison to the licensing system applied in many countries before the entry into force of this directive ${ }^{9}$. According to this new directive however, individual authorization system were used just for the allocation of scarce resources such as frequencies and numbers.

The heading of Article 4 of this directive is Minimum List of Rights Derived from the General Authorization and it is noted that general authorization covers at least the following rights: first of all, the most fundamental right granted by general authorization to the undertakings is the provision of electronic communications and services. Another right is to have applications for the necessary rights to install facilities considered in accordance with the framework directive. In addition, this article mentions the rights to be granted to undertakings when they provide electronic communications Networks or services to the public. These rights cover the right to negotiate interconnection with and where applicable obtain interconnection from other service providers and to provide different elements of a universal service and/or to cover different parts of national territory in accordance with the Universal Service Directive. Within this context, while the article accepts that some rights may only arise with the general authorization, it states that the use of some rights will arise when service providers start to render service to the public.

\footnotetext{
${ }^{8}$ Sub-commission Report, p.47.

${ }^{9}$ Maxwell W.: Europe's New Regulatory Toolbox, CommLaw Conspectus, Vol. 12, 2004, p.167.
} 
Articles 5, 6 and 7 of the directive are concerning the rights of use for radio frequencies and numbers, the conditions attached to the general authorization and to the rights of use for radio frequencies and for numbers and the procedure for limiting the numbers of right of use to be granted for radio frequencies respectively, and they state that allocation of radio frequency should be provided through transparent and non-discriminatory procedures. However, these conditions may be applied only when the efficient use of frequencies is achieved. In case of any probability of harmful interference, the use of radio frequencies where individual right of use is concerned will be subject to a general permit. In the event that it is required to grant individual rights to use frequencies, permission may be granted provided that effective use of frequency, which is a scarce resource, is ensured $^{10}$.

In Turkey, within the framework of the Telegraph and Telephone Law No.406 and Radio Law No.2813 and for the purpose of harmonizing with the cited directive, the Authorization Regulation on Telecommunication Services and Infrastructures dated 26.08.2004 was prepared. The aim of this Regulation is to introduce a simple authorization and general permission system based on records, in addition to ensuring harmonization with the directive No.2002/20/EC ${ }^{11}$. However, the efficiency level foreseen by the European Union regulations could not be reached as this legal regulation is not fully in harmony with the European Union's approach due to its ability to answer the needs partially and owing to the problems faced in practice ${ }^{12}$.

\section{Access Directive}

Another directive adopted in the framework of the New Regulatory Framework is the Access Directive 2002/19/EC. This Directive is basically concerning the provision of a market enjoying effective competition and the imposition of an obligation to provide cost-based interconnection in compliance with the principles of non-discrimination and transparency between operators having SMP ${ }^{13}$. The aim of the Access Directive is the provision of effective and sustainable competition and encouragement of investments. The principles considered in the cited directive are the principles

${ }^{10}$ Özenç K.: Avrupa Birliği’nde Telekomünikasyon Politikaları AB Müktesebatı ve Türkiye Tarafından Alınması Gereken Tedbirler Üzerine Bir Araştırma (Research of Telecommunication Policies in EU; EU Acquis Communautaire and Measures required to be taken by Turkey), Telekomünikasyon Kurumu Uzmanlık Tezi (Telecommunication Authority, Expert Thesis), April 2002, p.73.

11 Büyükbaş A.: Yetkilendirme Yönetmeliği (Sunum Metni) (Authorization RegulationPresentation Text), 2004, http://www.telekomkuumu.gov.tr/Etkinlikler/Ulusal_Etkinlikler/ Sempozyum/yetkilendirme.pdf (12.12.2007).

${ }^{12}$ Sub-commission Report, p.51.

13 Okan G.: Ara Bağlantı AB İlerleme Raporuna Uygun mu?-1 (Is interconnection in compliance with EU Progress Report?), http://turk.internet. com/haber/ yazi goster.php3?yaziid=11089 (12.12.2007); Kuzey, p.30. 
such as transparency, equality, encouragement of the provision of services at reasonable prices, consideration of special conditions of users and avoidance of cross-subsidy. These principles are mentioned in various articles of the directive.

The aim of the directive is defined in Article 1 "to harmonize the way in which Member States regulate access to and interconnection of electronic communication Networks and associated facilities." Again in the same article, it is stated that the Directive "sets out objectives for National Regulatory Authorities with regard to Access and interconnection, and lays down procedures to ensure that obligations imposed by national regulatory authorities are reviewed and where appropriate, withdrawn once the desired objectives have been achieved".

Article 2 of the directive is concerning definitions and "access" means the making available of facilities to another undertaking under defined conditions on an either exclusive or non-exclusive basis for the purpose of providing electronic communications services. It should be stated that the concept of "access" is defined very broadly in the directive and access not only to networks but also to all elements of these networks and services (network elements, buildings, antennas, software systems etc.).

"Interconnection" means the making of the physical and logical linking of public communications networks used by the same or a different undertaking in order to allow the users of one undertaking to communicate with users of the same or another undertaking, or to access services provided by another undertaking.

Other innovations introduced by the directive may be listed as transparency obligation for the operators having SMP, non-discrimination obligation, accounting separation obligation, obligation to submit reference offer in relation to access to local loop, obligation operators of public communication Networks to negotiate interconnection with each other, and obligations related to rates and cost accounting. It is accepted that these obligations shall be imposed only to the operators having SMP. This was criticized for giving birth to the probability that NRA may make differed practices in terms of the implementation of obligations ${ }^{14}$.

The developments in Turkey reveals the fact that "Access and Interconnection Regulation" dated 14.06.2007 was prepared in the process of harmonization with the European Union and the aim of the Regulation is defined in Article 1 in parallel to the directive; "The purpose of this Ordinance is to set out the principles and procedures regarding access to telecommunications networks including interconnection, so as to encourage

\footnotetext{
${ }^{14}$ Hocapied C.: New EU Regulatory Framework for Electronic Communications, Int'1 Bus.Law., Vol.30, 2002, p.292.
} 
the applications ensuring that the users draw maximum benefit from the telecommunications services and networks in return for a reasonable price, to provide efficiency and sustainable competition in telecommunications sector, to ensure interoperability of telecommunication services and to support investment in infrastructures to constitute competitive environment in so far it serves the long-term benefit of end-users."

In the abovementioned Regulation, access is defined as "making available of infrastructure and/or services of telecommunications by an operator to another operator", interconnection is defined as "connection of two networks for the realization of telecommunications traffic between two separate telecommunications networks". Article 5 of the Regulation states the principles predominating the Regulation, which cover the provision of sustainable competitive environment in accordance with the directive, continuity, orderliness, reliability, productivity, clarity, transparency and efficient use of resources, ensuring that national telecommunications market is at international standards and levels in line with changing conditions, etc. It is noted that harmonization with European Union was accomplished within this context; however what it is important is not to provide legal harmonization, but to observe such efficiency in practice.

\section{Competition Directive}

One of the most important objectives of the New Regulatory Frame that was prepared in 2002 is to provide competition significantly in this sector in which liberalization was recently gained. Although the removal of the judicial barriers to enter into telecommunication sector is an important step with liberalization, by considering the importance of the electronic communication services for the whole society, in order to protect the consumers and also prevailing entry barriers and network externalities in the sector, this step does not directly bring forward competition; the existence of a regulatory frame in which arrangements that are unique to the sector and competition law are jointly implemented in order to prevent operators to remain in de facto monopoly condition is required ${ }^{15}$.

In addition to the Competition Directive dated September 16, 2002 and numbered 2002/77/EC, various arrangements are mentioned in several directives of the New Regulatory Framework regarding significant usage of competition. In this context, in particular the Framework Directive shall be considered it appears that the articles of said directive numbered 14, 15 and

15 Demiröz A.; Avrupa Birliği'nin Yeni Düzenleyici Çerçevesi Işı̆̆ında Telekomünikasyon Sektörünün Düzenlenmesinde Rekabet Hukuku'nun Rolü, Rekabet Dergisi, S.15, Temmuz-Ağustos-Eylül 2003, s.18 ( Role of the Competition Law on Regulating The Telecommunication Sector Under the Light Of The New EU Regulatory Frame, Competition Review, N.15, July, August, September 2003, p.18). 
16 brought some new formulations indicating, "how ex-ante arrangement shall be implemented" in the New Regulatory Framework. Accordingly, the National Regulating Authorities shall determine the markets, which the Commission shall advise, by using the principles of the competition law, where ex-ante arrangements shall be implemented; and no ex-ante arrangements shall be introduced within said markets and existing ex-ante obligations on the existing operators shall be removed if there is a sufficient competition in the market. However if there is no significant competition in the markets, then the proper ex-ante obligations that are determined in specific directives shall be introduced to the related operators ${ }^{16}$. That is, the directive requires that the regulatory arrangements (ex-ante) shall be applied in the markets where significant competition does not exist and if full competition exist in the market, then deregulation should be implemented and the market shall be left to its own operation.

The term SMP is brought forward in order to measure whether or not effective competition is provided in the market. In 1998 directives, an arrangement requiring that the organizations that have market share exceeding $25 \%$ of the telecommunication market shall be considered to possess a specified market power was provided. However the Framework Directive has considered the SMP concept as equivalent to with the prevailing condition that is specific to competition law ${ }^{17}$. However the directive has also brought forward the "collective dominance" and "closely related markets" terms and expanded the SMP in order to include the conditions apart from single dominance concept. Hence in our country the determination of the enterprises that have SMP was left to the initiative of Telecommunication Board and within this frame, the Board determined enterprises having dominant position or SMP by considering such criteria's including the market share, entry barrier into market, the power to influence the market conditions ${ }^{18}$.

Whereas the rules that are brought forward in order to secure competition by Access Directive are the liabilities that are implemented only enterprises having SMP. In this frame the ex-ante liabilities that are brought to the enterprises that have SMP were implemented in order to prevent abusing of the SMP or in other words, the dominant conditions of said enterprises. Whereas the directive numbered 2002/77/EC repeats some of the rules that are appeared in above-mentioned directives. In this content, the directive seeks for bringing together the rules that remained as scattered. The

\footnotetext{
${ }^{16}$ Demiröz, p.24.

17 Demiröz, p.24-25; Maxwell p. 167; Ardiyok Ş.: Competition in Local Telecommunication Services, Competition Board Expertise Thesis, Ankara 2004, p.55.

${ }^{18}$ Ekici Ş.: Özel Sektöre Açıldıktan Sonra Türk Telekomünikasyon Hukuku (Elektronik İletişim), İstanbul 2006, s.109-10 (Turkish Telecommunication Law After Open The Private Sector (Elektronic Communication), İstanbul 2006, p.109-110).
} 
Commission reminds the member states that they may have violated the competition rules that are mentioned in the European Union Convention if the rules regarding competition in other directives are not applied. Hence the provisions regarding competition that are mentioned in European Union Convention are repeated in the directive ${ }^{19}$.

In Turkey, after all of the telecommunication network and services markets are opened to competition in January 1, 2004, a well designed regulating frame is required in order to encourage the newly entered actors to the market, and to provide legal guarantees against the undue acts of the incumbent operators violating competition and also to further improve and maintain the competition in competitive markets. At this point it may be possible to be benefited from the New Regulatory Frame model of EU. By considering the liberalization trend and also the increasing expectations in investments after the privatization of Turkish Telecom, under the light of important interventions by the Competition Board, there is a need for a guide that would describe how the competition code would be applied in this sector in order to provide to legal certainty for investors ${ }^{20}$.

\section{The Developments That Are Brought Forward By The European Union Reform Package Dated November 13, $2007^{21}$}

The latest development that was implemented in the European Union regarding this sector is two directives and one regulation drafts that are completed by EU, presented to the Commission and envisages amendment in the 2002 Package.

The reforms that are presented by said amendment may generally be collected under four headings. If particularly the arrangements regarding the competition in the sector are to be considered, it should be specified that competition mean offering more alternatives to the sector. It is necessary to increase competition in order to offer more investments, more innovations, and lower price in telecommunication sector. Therefore the first of these reforms is specified as to decrease the number of markets that require ex-ante arrangement and in this frame, commission has decreased the number of markets from 18 as previously determined to 7 . This development also represents developments for providing a proper competition atmosphere and protection of consumer rights. Another reform that is brought forward within

\footnotetext{
${ }^{19}$ Maxwell, p.168.

${ }^{20}$ Demiröz, p.36.

${ }^{21}$ Freshfields Burckhaus Deringer, Intense Debates Expected on EU Telecoms Reform Package (Briefing), Kasim 2007, http://www.freshfields.com/publications/pdfs/2007/nov21/ 20821.pdf (13.12.2007); Europe's Information Society Thematic Portal, Proposals For Reform,http://ec.europa.eu/information_society/policy/ecomm/tomorrow/reform/index _en.htm (13.12.2007); Vandystadt N.:EU Launches Itself info Vast Reform of "Telecoms Package", http://vvww.europolitics.info/xg/features/Telecoms/211138?is PortalAccessed=true $(13.12 .2007)$.
} 
this content is the functional separation of the network and services of the operators. By said regulation it is accepted that the national regulating authorities would subject the service and infrastructure constructing portions into a functional separation. This separation seeks the provision of equality for the competent operators for find access to infrastructure services and to enable maintenance of competition in an efficient way ${ }^{22}$.

Another objective that is foreseen is the strengthening of the domestic market. The inclusion and evaluation of the European Union directives into the national law as differently lead to inconsistency among the national laws of the member states and this in turn leads to an obstacle for opening of the service providers into the other member states markets. Yet, the service providers request to be subjected to same rules everywhere in Europe. Therefore some proposals are brought forward in draft directive for the cooperation of independent regulatory authority and also the objective for formation of a European Electronic Communication Market Authority is mentioned among the headings of the proposal ${ }^{23}$.

Another objective is more efficient protection of the consumers. The European Union has brought forward several arrangements in order to protect the consumer in the directives that were prepared in 2002. Said rights are particularly focused on the access to telephone and internet connection, protection of personal information and to facilitate access to certain services by the handicapped citizens. According to said draft, the operators are liable to facilitate the procedures to switch from one operator to another operator, to present transparent and comparable price information, to facilitate access to free calls from abroad, to activate the arrangements for the handicapped and to facilitate the access to joint European emergency service call number of 122. Apart from them, the consumers are setting getting distressed and worried for abusing of financial information in connection with the protection of personal information. A Chief Network Security Officer that reports to European Electronic Communication Market is planned to be appointed in order to decrease said worry down to a minimum and to prevent the harmful software which are known as spam or spyware. Its duty is to determine the conditions that jeopardize the protection of personal data by cooperating with regulatory authorities and to prevent occurrence of said risk ${ }^{24}$.

\footnotetext{
${ }^{22}$ Freshfields Burckhaus Deringer, Intense Debates Expected on EU Telecoms Reform Package (Briefing),Kasim2007,http://www.freshfields.com/publications/pdfs/2007/nov21/20821.pd f (13.12.2007); Europe's Information Society Thematic Portal, Proposals For Reform, http://ec.europa.eu/information_society/policy/ecomm/tomorrow/reform/index_en.htm (13.12.2007); Vandystadt $\mathrm{N} .: E U$ Launches Itself info Vast Reform of "TelecomsPackage", http://vvww.europolitics.info/xg/features/Telecoms/ 211138?is PortalAccessed=true (13.12.2007).

23 Europe's Information Society Thematic Portal, http://ec.europa.eu/information_society/ ecomm/tomorrow/reform/index_en.htm 13.12.2007).

24 Europe's Information Society Thematic Portal, http://ec.europa.eu/information
} 
Finally the objectives on this matter include to facilitate access to spectrum being the backbone of all of the wireless communication services, to remove the unnecessary restrictions in spectrum use, to make investments to infrastructure on this matter and to provide broad band access to everyone, and to use the Spectrum from wireless wideband services at regions where construction of new infrastructure is too costly and thereby to decrease the digital gap. Beside making the arrangement regarding the radio spectrum more flexible and market base, it is also aimed to regulate the spectrum, which is assumed scarce source to provide maximum benefit ${ }^{25}$.

\section{Conclusion}

In conclusion, the directives were formulated after 1998 and were subjected to regulation by the New Regulating Framework that was prepared in 2002. The directives help to ensure efficiency in the market place and the protection of consumers. In light of these directives, it is apparent that the EU seeks become more efficient by systemically organizing rules, but it is not easy to state whether or not the rules that are included in the directives are able to fulfill the goals set by the framers of the rules given that the directives are implemented by member states in to their own legislation, which may give rise to fragmentation in the union. The diversified procedures that encountered in adopting such rules according to their national legislation appears to be a handicap for the national operators to extend their services into other states of Europe. It is foreseen that said problem could be prevented and resolved not by forming new directives and new rules, but by collecting the National Regulating Authorities under the same roof. Hence the objective of the reform package appears to be implementing the internal arrangements through enforcing the deregulation procedures.

society/ecomm/tomorrow/Reform/index_en.htm (13.12.2007)

${ }^{25}$ İktisadi Kalkınma Vakfı (Economic Development Foundation) Weekly E-Bulletion 12-18 November 2007, p.5, http://miad.org.tr/php/duyurular/ikv_ 12_18_kasim.pdf (13.12.2007);Freshfields Burckhaus Deringer, http://www.freshfields.com/ publications/pdfs/2007/nov21/20821.pdf (13.12.2007); Europe's Information Society Thematic Portal, http://ec.europa.eu./information_society/policy/ecomm/tomorrow/reform /index_en.htm (13.12.2007). 


\section{BIBLIOGRAPHY}

Ardıyok Ş.: Yerel Telekomünikasyon Hizmetlerinde Rekabet, Rekabet Kurumu Uzmanlık Tezi, Ankara 2004.

(Competition in Local Telecommunication Services, Competition Board Expertise Thesis, Ankara 2004).

Craig P./ De Burca G.: EU Law,Oxford 2003.

Demiröz A.: Avrupa Birliği'nin Yeni Düzenleyici Çerçevesi Işı̆̆ında Telekomünikasyon Sektörünün Düzenlenmesinde Rekabet Hukuku'nun Rolü, Rekabet Dergisi, S.15, Temmuz-Ağustos-Eylül 2003, s. 15-40.

(Role of the Competition Law on Regulating The Telecommunication Sector Under the Light Of The New EU Regulatory Frame, Competition Review, N.15, July, August, September 2003, p.15-40)

Ekici Ş.: Özel Sektöre Açıldıktan Sonra Türk Telekomünikasyon Hukuku (Elektronik İletişim), İstanbul 2006.

(Turkish Telecommunication Law After Open The Private Sector (Elektronic Communication), İstanbul 2006)

Hocapied C: New EU Regulatory Framework far Electronic Communications., Int'l Bus. Law.? Vol 30, 2002, s.291-296.

Kuzey P.: Avrupa Birliği'ne Üyelik Perspektifinde Türkiye'de Telekomünikasyon Sektörüne Bir Bakış, Bütçe Dünyası, C.2, S.25, Bahar 2007, s,28-39.

(Approach to Telecommunication Sector in Turkey in the Perspective of Membership to European Union), Budget World, V.2, S.25, Spring 2007, p.30).

Maxwell W.: Europe 's New Regulatory Toolbox, CommLaw Conspectus, Vol. 12, 2004,s.161-168.

Özenç K.: Avrupa Birliği'nde Telekomünikasyon Politikaları AB Müktesebatı ve Türkiye Tarafından Alınması Gereken Tedbirler Üzerine Bir Araştırma, Telekomünikasyon Kurumu Uzmanlık Tezi, Nisan 2002.

(Research of Telecommunication Policies in EU; EU Acquis Communautaire and Measures required to be taken by Turkey, Telecommunication Authority, Expert Thesis, April 2002, p.73).

Weatherill S./Beamont P.: EU Law, London 1999. 
Zerey G.: Avrupa Birliği Elektronik Haberleşme Müktesebatına Göre Telekomünikasyon Sektörünün Düzenlenmesi (Sunum Metni), İstanbul 2006, ), (Regulation of Telecommunication Sector according to European Union's Electronic Communication Acquis Communautaire-Presentation Text) http://www.tgm.gov.tr/Etkinlikler /Ulusal_Etkinlikler/sunumlar/gzerey_sunum_3.pps\#256

\section{Reviewed Directives:}

1- Yetkilendirme Direktifi (Authorization Directive)

2- Rekabet Direktifi (Competition Directive)

3- Erişim Direktifi (Access Drective)

4- 13 Kasim 2007 Tarihli Taslak (Draft November 13, 2007): Freshfields Burckhaus Deringer, Intense Debates Expected on EU Telecoms Reform Package (Briefing), Kasim 2007, http://www.freshfields.com/publications/pdfs/2007/nov21/20821.pdf( 13.12.2007); Europe's Information Society Thematic Portal, Proposals ForReform,http://ec.europa.eu/information_society/ policy/ecomm/tomorrow/reform/index_en.htm (13.12.2007); Vandystadt N.:EU Launches Itself info Vast Reform of "Telecoms Package", http://vvww.europolitics.info/xg/features/Telecoms/ 211138?isPortalAccessed=true $\quad(13.12 .2007)$. 